\title{
11/-hydroxysteroid dehydrogenase- 1 is associated with the activation of hepatic stellate cells in the development of hepatic fibrosis
}

\author{
WEI XIAO ${ }^{1,2}$, MENG-HOU LU ${ }^{2}$, PENG-FEI RONG ${ }^{3}$, HAO-YE ZHANG $^{1}$, JIAN GONG $^{1}$, \\ YING-QIONG PENG ${ }^{1}$, HUAN-YU GONG ${ }^{1}$ and ZHEN-GUO LIU ${ }^{1}$
}

\author{
${ }^{1}$ Department of Infectious Disease, The Third Xiangya Hospital, Central South University, Changsha, Hunan 410013; \\ ${ }^{2}$ Department of Infectious Disease, Xiangya Hospital, Central South University, Changsha, Hunan 410008; \\ ${ }^{3}$ Department of Radiology, The Third Xiangya Hospital, Central South University, Changsha, Hunan 410013, P.R. China
}

Received July 30, 2019; Accepted June 19, 2020

DOI: $10.3892 / \mathrm{mmr} .2020 .11423$

\begin{abstract}
Hepatic fibrosis (HF) is a common complication of numerous chronic liver diseases, but predominantly results from persistent liver inflammation or injury. If left untreated, HF can progress and develop into liver cirrhosis and even hepatocellular carcinoma. However, the underlying molecular mechanisms of HF remain unknown. The present study aimed to investigate the role of $11 \beta$-hydroxysteroid dehydrogenase-1 (11 $\beta$-HSD1) during the development of hepatic fibrosis. An experimental rat model of liver fibrosis was induced using porcine serum. 11 $\beta$-HSD1 gene expression levels and enzyme activity during hepatic fibrogenesis were assessed. 11 $\beta$-HSD1 gene knockdown using small interfering RNA and overexpression were performed in LX2-human hepatic stellate cells (HSCs). HSCs were stimulated with transforming growth factor- $\beta 1$ (TGF- $\beta 1$ ). Cell cycle distribution, proliferation, collagen secretion and 11 $\beta$-HSD1 gene activity in HSCs were compared before and after stimulation. As hepatic fibrosis progressed, 11 $\beta$-HSD1 gene expression and activity increased, indicating a positive correlation with typical markers of liver fibrosis. 11 $\beta$-HSD1 inhibition markedly reduced the degree of fibrosis. The cell proliferation was increased, the number of cells in the $G_{0} / G_{1}$ phase decreased and the number of cells in the $S$ and $G_{2} / M$ phases increased in the pSuper transfected group compared with the $\mathrm{N}$ group. In addition, the overexpression of $11 \beta$-HSD1 enhanced the TGF- $\beta 1$-induced activation of LX2-HSCs and enzyme activity of connective tissue growth factor. 11 $\beta$-HSD1 knockdown suppressed cell proliferation by blocking the $G_{0} / G_{1}$ phase of the cell cycle, which was
\end{abstract}

Correspondence to: Dr Zhen-Guo Liu, Department of Infectious Disease, The Third Xiangya Hospital, Central South University, 138 Tongzipo Road, Changsha, Hunan 410013, P.R. China

E-mail: liuzhenguo@csu.edu.cn

Key words: 11ß-hydroxysteroid dehydrogenase-1, hepatic fibrosis, hepatic stellate cells associated with HSC stimulation and inhibition of 11ß-HSD1 enzyme activity. In conclusion, increased 11 $\beta$-HSD1 expression in the liver may be partially responsible for hepatic fibrogenesis, which is potentially associated with HSC activation and proliferation.

\section{Introduction}

$11 \beta$-hydroxysteroid dehydrogenases (11 $\beta$-HSD) are a class of oxidoreductases that catalyze the reversible transformation between corticosterone and dehydrocorticosterone. 11 $\beta$-HSD can be divided into two isoforms in humans: $11 \beta-H S D 1$ and $11 \beta$-HSD2 (1). 11 $\beta$-HSD1 is a crucial enzyme that converts inactive cortisone into active hydrocortisone, thus regulating multiple functions of glucocorticoids (GCs) (2). 11ß-HSD1 is widely expressed in tissues (3) and is particularly abundant in the liver, muscle and fat tissue (4). In renal tissue, 11 $\beta$-HSD1 exhibits oxidase activity, whereas in non-renal tissues, such as liver and fat tissues, $11 \beta$-HSD1 exhibits reductase activity. In particular, the role of $11 \beta$-HSD1 in the liver is associated with elevated levels of active GCs, which is consistent with increased levels of GCs in liver fibrosis (5). Therefore, it has been speculated that $11 \beta-H S D 1$ is involved in the early activation and signal transduction of hepatic stellate cells (HSCs) and may regulate the expression of extracellular matrix (ECM) components (6-9).

Hepatic fibrosis is a common pathophysiological feature of all chronic liver diseases (10). HSCs are the final target cell type of various profibrotic factors (11), serving as key mediators in the occurrence and development of hepatic fibrosis (12-15). Once HSCs are activated by inflammatory factors, including transforming growth factor (TGF)- $\beta 1$ (16), their phenotype changes from resting to activated and then into myofibroblasts (MFB), which secrete abundant ECM components (17), resulting in increased ECM deposition and reduced matrix decomposition (18). Furthermore, activated HSCs exhibit reduced cell cycle, accelerated proliferation rates (19), increased numbers (20), decreased amounts of fat and vitamin A storage (21), and secretion of profibrotic factors $[\alpha$-smooth muscle actin ( $\alpha$-SMA) and connective 
tissue growth factor (CTGF)], which further stimulate HSC activation $(19,22)$, resulting in a feedback mechanism (23). Activated HSCs promote the synthesis and secretion of tissue inhibitor of metalloproteinase (24) and inhibit the degradation of ECM by matrix metalloproteinases, thus promoting liver fibrogenesis (25). ECM is primarily composed of three types of organic substances: Collagen, glycoprotein and proteoglycan. Among these, type IV collagen (Col IV), N-terminal pro-peptide of collagen type III (PIIINP) and hyaluronic acid (HA) are often used as serological indicators of the degree of hepatic fibrosis $(26,27)$. In addition, liver hydroxyproline (Hyp) content, a unique amino acid component of collagen, can reflect alterations in collagen metabolism, parallel to the degree of hepatic fibrosis (28). As an antigen substance, xenogeneic serum induces an immunoresponse in the liver, leading to the formation of immune complexes. If the excessive immune complexes are not removed in a timely manner, they are deposited in the liver and the hepatic vascular wall, causing cell infiltration, release of inflammatory mediators, cell degeneration of parenchymal liver cells, fibrous hyperplasia and hepatic fibrosis $(27,29,30)$.

The present study developed an in vivo model of hepatic fibrosis in rats using porcine serum. In addition, using in vitro cell culture, LX2-HSCs were stimulated with TGF- $\beta 1$. The two experimental approaches were established to systematically investigate alterations in $11 \beta-H S D 1$ expression and activity in liver tissue and HSCs during hepatic fibrogenesis. Furthermore, the effects of $11 \beta$-HSD1 knockdown and overexpression on the development and progression of hepatic fibrosis and its underlying mechanism of action were studied in LX2-HSCs.

\section{Materials and methods}

Experimental animals. A total of 108 male Sprague Dawley (SD) rats (age, 4-6 weeks; weight, 130-150 g) in quarantine were obtained from Hunan SJA Laboratory Animal Co. Ltd. The SD rats were housed in barrier rooms at $22 \pm 2^{\circ} \mathrm{C}$ with 65-70\% humidity, a 12-h light/dark cycle and free access to water and food. Rats were randomly assigned to the following three groups ( $\mathrm{n}=36$ per group): i) Normal control group $(\mathrm{N})$; ii) the model group (M); and iii) the $11 \beta$-HSD1 inhibitor group $(\mathrm{M}+\mathrm{I})$. Rats in the $\mathrm{M}$ and $\mathrm{M}+\mathrm{I}$ groups received an intraperitoneal injection of $0.5 \mathrm{ml}$ porcine serum (Beijing Solarbio Science \& Technology Co., Ltd.) twice a week. The $\mathrm{N}$ group received an equal volume of $0.9 \% \mathrm{NaCl}$ via intraperitoneal injection at the same frequency for the same duration. In addition to porcine serum administration, rats in the M+I group were treated with the $11 \beta-H S D 1$ inhibitor BVT.2733 $(100 \mathrm{mg} / \mathrm{kg})$, which was orally administrated by gavage. At 5,10 and 15 weeks following treatment, 12 rats in each group were anesthetized with an intraperitoneal injection of $2 \%$ pentobarbital sodium ( $30 \mathrm{mg} / \mathrm{kg}$ body weight) and deep anesthesia was verified by moderate respiratory and cardiovascular depression, and good muscle relaxation. The experimental rats were euthanized by cervical dislocation. The abdominal aorta and right lobe of the liver were collected for subsequent experiments. Prior to sacrifice, $2 \mathrm{ml}$ blood was collected from the abdominal aorta of the rats, which was stored at $4^{\circ} \mathrm{C}$.
All animal experiments were performed in accordance with the guidelines of The Institutional Animal Care and Use Committee of Xiang [license no. SCXK (Xiang) 2011-0003].

Experimentalreagents. The 11 $\beta$-HSD1 inhibitor,BVT.2733, was purchased from MedChem Express. Rat TGF- $\beta 1$ was purchased from Abbkine Scientific Co., Ltd. (cat. no. PRP100618). The anti-11 $\beta$-HSD1 antibody was purchased from AtaGenix (cat. no. ATA24000; 1:200). Human TGF- $\beta 1$ was purchased from PeproTech, Inc. (cat. no. AF-100-21). Rat Col IV (cat. no. MBS704982) and PIIINP ELISA kits (cat. no. MBS704287), and the Annexin V-FITC/PI apoptosis detection kit (cat. no. MBS355226) were purchased from MyBioSource, Inc. The HA ELISA kit was purchased from R\&D Systems (cat. no. DHYAL0). The ProCell collagen colorimetric assay kit was purchased from Genmed Scientifics, Inc. (cat. no. GMS10373.8). The rabbit-derived rat $\alpha$-SMA (cat. no. ab124964; 1:1,500), CTGF (cat. no. ab6992; 1:2,000) and $\beta$-actin (cat. no. ab8227; 1:1,000) primary antibodies, and the goat anti-rabbit secondary IgG-HRP antibody (cat. no. ab97080; 1:5,000) were all purchased from Abcam. The cortisol kit (11 $\beta$-HSD1 activity detection kit) was purchased from Cisbio (cat. no. 62CRTPEG). The adenovirus and adenovirus vector were purchased from Miao Ling Biotechnology Co., Ltd. (cat. nos. P0241 and P0653). The Cell Counting Kit-8 (CCK-8) cell proliferation test kit (cat. no. CK04) was purchased from Dojindo Molecular Technologies, Inc.

Pathological examination of livers. At weeks 5, 10 and 15 of treatment, 12 rats were randomly selected, anesthetized with $2 \%$ pentobarbital sodium and sacrificed. The abdominal aorta and right lobe of the liver were harvested for pathological examinations. In brief, the tissues were fixed for 7 days in $4 \%$ neural-buffered formalin at room temperature, dehydrated in increasing concentrations of ethanol, embedded with paraffin wax and sliced into $4 \mu \mathrm{m}$-sections, and comparative pathological alterations were observed via hematoxylin (5-20 $\mathrm{min})$ and eosin staining (10-30 $\mathrm{min})$, both at room temperature. The stages of fibrosis were examined by two independent experienced pathologists using the following pathological scoring criteria (31): 0 , no liver fibrosis; I, degeneration of hepatocytes with $\leq 0.5$ of the radius of hepatic lobules and infiltration of inflammatory cells surrounding the portal area; II, degeneration of hepatocyte $>0.5$ of the radius of hepatic lobules, with primarily balloon-like degeneration, a large number of infiltrating inflammatory cells and obvious fibrous tissue hyperplasia in the portal vein; and III, degeneration and necrosis of hepatocytes extended to 0.66 of the radius of hepatic lobules with fragmentation and bridging necrosis of hepatocytes, and lots of fibrosis in the parenchyma.

Measurement of serum Col IV, HA and PIIINP via ELISA. Blood samples were centrifuged at $1006.2 \mathrm{x}$ g for $15 \mathrm{~min}$ at $4^{\circ} \mathrm{C}$ to obtain serum. The concentrations of Col IV, HA and NPIIINP in the serum of the rats were detected using ELISA kits, according to the manufacturer's protocol.

Western blotting. Total protein from the liver tissues was extracted with ice-cold RIPA lysis buffer (Beyotime Institute of Biotechnology), containing $50 \mathrm{mM}$ Tris, $150 \mathrm{mM} \mathrm{NaCl}$, 
$1 \%$ Triton $\mathrm{X}-100,1 \%$ sodium deoxycholate, $0.1 \%$ SDS and $1 \mathrm{mM}$ protease inhibitor PMSF. Total protein was quantified using a bicinchoninic acid assay to correct the sampling volume and $30 \mu \mathrm{g}$ protein/lane was separated via 10\% SDS-PAGE. The separated proteins were subsequently transferred onto nitrocellulose membranes (EMD Millipore) and blocked with $5 \%$ BSA (Beyotime Institute of Biotechnology) for $1 \mathrm{~h}$ at room temperature. The membranes were then incubated with the primary antibodies for $1 \mathrm{~h}$ at room temperature. Following the primary antibody incubation, the membranes were washed with 1 X TBS-1\% Tween-20 (TBST) three times for 15 min each and incubated with the secondary antibodies $(1: 2,000$; Boster Biological Technology; cat. nos. BA1050 and BA1054) $1 \mathrm{~h}$ at room temperature. The membrane was subsequently washed with 1X TBST twice for $15 \mathrm{~min}$ and $1 \mathrm{X}$ TBS once for $15 \mathrm{~min}$. Protein bands were visualized using a SuperSignal West Pico Chemiluminescent substrate (Thermo Fisher Scientific, Inc.) and protein expression was quantified using ImageJ v1.8.0 software (National Institutes of Health).

Measurement of Hyp in liver tissues. Hyp content in the liver tissue was detected using an A030-2 kit (Nanjing Jiancheng Bioengineering Institute) according to the manufacturer's instructions. In brief, liver tissues $(\sim 200 \mathrm{mg})$ were homogenized and incubated overnight at $110^{\circ} \mathrm{C}$. After filtering acid hydrolysates with a $0.45 \mu \mathrm{m}$ filter, samples or Hyp standards $(50 \mu \mathrm{l})$ were dried at $60^{\circ} \mathrm{C}$, dissolved with methanol $(50 \mu \mathrm{l})$ and treated with $1.2 \mathrm{ml} \mathrm{50 \%}$ isopropanol and $200 \mu \mathrm{l}$ chloramine-T solution at room temperature for $10 \mathrm{~min}$. Ehrlich's solution $(1.3 \mathrm{ml})$ was added and the samples were further incubated at $50^{\circ} \mathrm{C}$ for $90 \mathrm{~min}$. The optical density was read at a wavelength of $558 \mathrm{~nm}$ using a spectrophotometer. A standard curve was constructed using serial two-fold dilutions of $1 \mathrm{mg}$ hydroxyproline solution.

Detection of $11 \beta$-HSDl activity in liver tissue and HSCs. Liver tissues (1.5-2.0 g) were homogenized in PBS, and the resulting homogenate was centrifuged at $1,000 \times \mathrm{g}$ at $4^{\circ} \mathrm{C}$ for $5 \mathrm{~min}$. The supernatant was collected and centrifuged at $42,000 \mathrm{x} \mathrm{g}$ for $3 \mathrm{~min}$ at $4^{\circ} \mathrm{C}$. The protein concentration of the supernatant was determined using the bicinchoninic acid method. The supernatant was placed in an ice bath for subsequent analysis. HSCs were lyzed and total protein was quantified using the bicinchoninic acid assay. $11 \beta$-HSD1 activity in the supernatant of rat liver tissue and total protein of HSCs was detected using the cortisol kit according to the manufacturer's instructions.

Preparation, culture and verification of rat primary HSCs. Primary HSCs were obtained from 20 additional SD rats (all details on rats and housing the same as above) by perfusion with Pronase E/Collagenase IV. Briefly, the rats were euthanized with $30 \mathrm{mg} / \mathrm{kg}$ body weight sodium pentobarbital and $\mathrm{CO}_{2}$ (20\% container volume/min). After determining that the rats were immobile, not breathing and the appearance of pupil dilation, the abdomen of the rats was disinfected with $75 \%$ ethanol. The abdominal cavity was opened to expose the inferior vena cava and liver. The inferior vena cava was clipped, and the portal vein was cut, and a syringe pump was used to infuse EGTA solution $\left(20 \mathrm{ml} / \mathrm{ml}\right.$ at $\left.40^{\circ} \mathrm{C}\right)$ from the inferior vena cava into the liver at a constant rate until the liver turned white. Subsequently, the liver was infused with $15 \mathrm{ml}$ Pronase E solution and $20 \mathrm{ml}$ Collagenase IV solution for $20 \mathrm{~min}$ each at $37^{\circ} \mathrm{C}$. The liver was separated from the abdominal cavity and plated in a 100-mm Petri dish, then $5 \mathrm{ml}$ Pronase E (0.2 g/l)/Collagenase IV (0.2 g/l) digestion solution was added to digest the liver tissue at $37^{\circ} \mathrm{C}$ for $15 \mathrm{~min}$. The liver was crushed with ophthalmic scissors and a pipette was used to disperse the hepatocytes. The digested hepatocyte suspension was transferred to a $50 \mathrm{ml}$ centrifuge tube and shook for $25 \mathrm{~min}$ on a plate shaker at $37^{\circ} \mathrm{C}$. Subsequently, $10 \mathrm{ml}$ pre-chilled rat HSC complete medium $\left(4^{\circ} \mathrm{C}\right.$; cat. no. CM-R041; Procell Life Science \& Technology Co., Ltd.) was added to stop the digestion. After filtering through a 200-mesh screen, the suspension was placed in a $50 \mathrm{ml}$ centrifuge tube to undergo one-step density gradient centrifugation with $18 \%$ Nycodenz (W/V) at $1,450 \mathrm{x}$ g for $22 \mathrm{~min}$ at room temperature. Trypan blue staining was conducted to evaluate the relative population of living $\mathrm{HSCs}$ at $37^{\circ} \mathrm{C}$ for $3 \mathrm{~min}$. Quiescent HSCs were examined under a fluorescence microscope and appeared blue under UV light irradiation (328 nm wavelength). Desmin immunocytochemistry was conducted to determine the purity of the isolated primary HSCs. After culture in DMEM (Sigma-Aldrich; Merck KGaA) supplemented with 20\% FBS (Biological Industries) at $37^{\circ} \mathrm{C}$ for $24 \mathrm{~h}$, the majority of HSCs had attached to the dishes. Cell culture medium was replaced with DMEM containing $0.5 \% \mathrm{FBS}$ and cultured at $37^{\circ} \mathrm{C}$ for another $24 \mathrm{~h}$. Subsequently, $5 \times 10^{6} \mathrm{HSCs}$ were treated with or without $5 \mathrm{ng} / \mathrm{ml} \mathrm{TGF}-\beta 1$ at $37^{\circ} \mathrm{C}$ for another $48 \mathrm{~h}$.

Immunocytochemistry. Rat HSCs were inoculated into a petri dish containing coverslips and treated with or without TGF- $\beta 1$. After cells were grown to a monolayer, the coverslips were removed and washed twice with $1 \mathrm{X}$ PBS. The cells were fixed with $4 \%$ paraformaldehyde for $10 \mathrm{~min}$ at room temperature, after which the slides were washed with 1X PBS for $5 \mathrm{~min}$ and the cells were permeabilized with $0.5 \%$ Triton for $15 \mathrm{~min}$ at room temperature. The slides were then washed twice with 1X PBS for 5 min each, blocked with 1\% BSA (Beyotime Institute of Biotechnology) solution for $30 \mathrm{~min}$ at room temperature and incubated with the primary antibody diluted with $1 \% \mathrm{BSA}$ solution at $37^{\circ} \mathrm{C}$ for $2 \mathrm{~h}$. Subsequently, the slides were incubated with Alexa Fluor 488-labeled goat anti-rabbit secondary antibody (cat. no. bs-0295G-AF488; BIOSS) diluted with $1 \% \mathrm{BSA}$ solution at $37^{\circ} \mathrm{C}$ for $1 \mathrm{~h}$, washed twice with $1 \mathrm{X}$ PBS for 5 min each time and stained with a $5 \%$ DAPI solution at room temperature for $2 \mathrm{~min}$. Subsequently, the slides were mounted with an anti-quenching sealer and visualized under a fluorescence microscope (magnification, x200).

$11 \beta$-HSDl gene knockdown and overexpression in LX2-HSCs. To overexpress $11 \beta$-HSD1, the expression plasmid pSuper-11 $\beta$-HSD1 was constructed. Briefly, the full-length $11 \beta$-HSD1 cDNA was synthesized by Miao Ling Biotechnology Co., Ltd. and inserted into the parental vector pSuper (Addgene, Inc.). The pSuper-11 $\beta$-HSD1 expression vector was confirmed by double enzymatic digestion with Bam $\mathrm{H} 1 / \mathrm{XhoI}$ and sequencing. The custom interference plasmids, including small interfering (si)RNA-11 $\beta$-HSD1 and non-specific control (NC) siRNA-11 $\beta$-HSD1-NC, were purchased from Miao Ling Biotechnology Co., Ltd. The sequences of the 


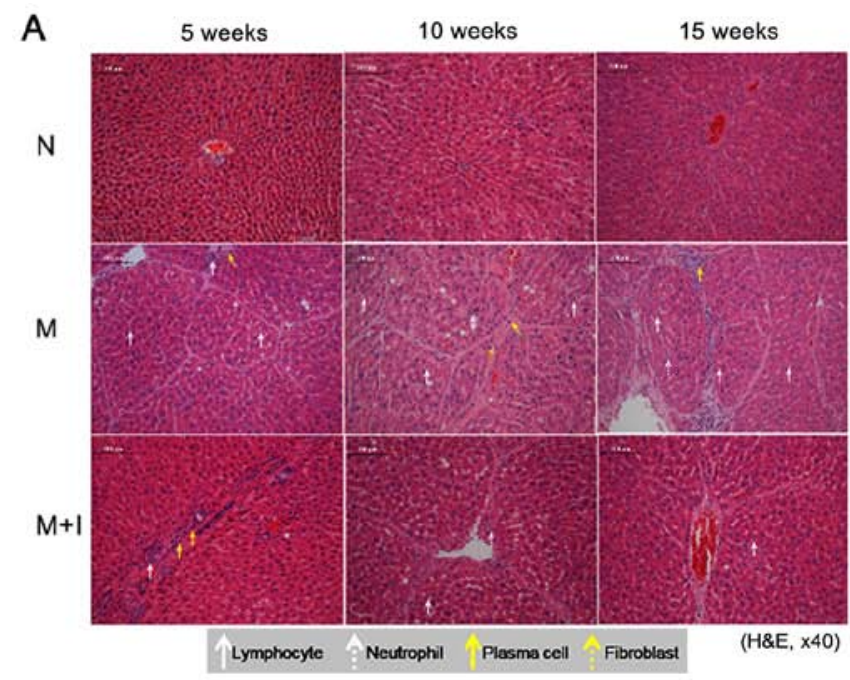

B

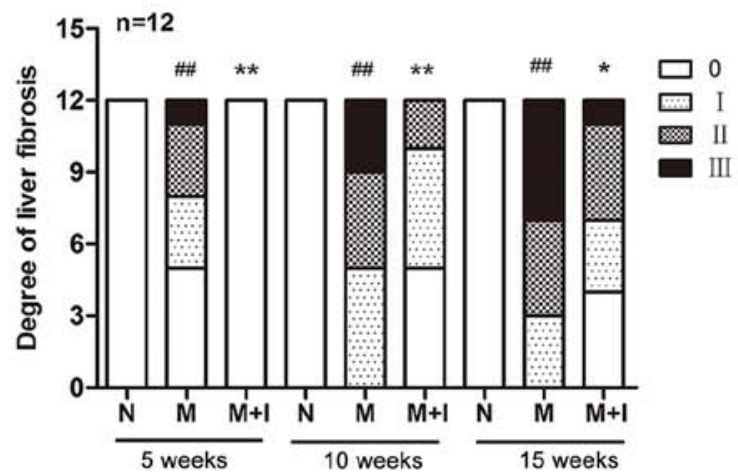

Figure 1. Effect of BVT.2733 on porcine serum-mediated liver fibrosis in rats. Liver tissues were obtained from the following three groups: i) N; ii) M; and iii) M+I. Pathological alterations were analyzed using H\&E staining. (A) Representative images of H\&E staining (magnification, $x 40$ ). Inflammatory cell infiltration was observed in the portal area of the liver in the positive group; no obvious indication of degeneration, necrosis and fibrotic tissue hyperplasia was observed. (B) Quantitative analysis of the histological images. ${ }^{\# \prime} \mathrm{P}<0.01 \mathrm{vs.} \mathrm{N;}{ }^{* *} \mathrm{P}<0.01$ and ${ }^{*} \mathrm{P}<0.05$ vs. M. N, normal control group; M, model group;

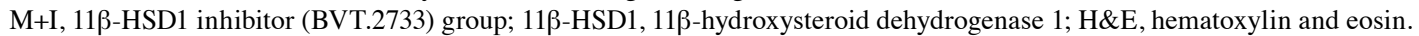

siRNAs were as follows: siRNA-11 3 -HSD1 sense, 5'-CAGAG AUGCUCCAAGGAAAGATT-3' and antisense, 5'-UUUCCU UGGAGCAUCUCUGGUTT-3'; and siRNA-11 $\beta$-HSD1-NC sense, 5'-UUCUCCGAACGUGUCACGUTT-3' and antisense, 5'-ACGUGACACGUUCGGAGAATT-3'. A total of $5 \times 10^{6}$ LX2-HSCs cells were divided into the following groups: i) Normal control group (N); ii) the siRNA group, in which LX2-HSCs were transfected with $2 \mu \mathrm{g}$ interference plasmid siRNA-11 $\beta-H S D 1$ and expression of $11 \beta-H S D 1$ was silenced; iii) the negative control group (NC), in which LX2-HSCs were transfected with $50 \mathrm{nM}$ plasmid siRNA-11ß-HSD1-NC; iv) the pSuper group, in which LX2-HSCs were transfected with $1 \mu \mathrm{g}$ pSuper-11 $\beta$-HSD1 plasmid to overexpress $11 \beta$-HSD1; and v) the Vec group, in which LX2-HSCs were transfected with $1 \mu \mathrm{g}$ pSuper-11 $\beta$-HSD1 plasmid, which was used as a control. All cells were transfected using Lipofectamine ${ }^{\circledR} 2000$ reagent (Invitrogen; Thermo Fisher Scientific, Inc.). At $72 \mathrm{~h}$ post-transfection, total protein was extracted and the expression of $11 \beta-H S D 1$ was measured in each experimental group by western blotting.

Cell cycle distribution and HSC proliferation. HSC proliferation was measured after 12, 24, 48, 72 and $96 \mathrm{~h}$ of culture using the CCK- 8 cell proliferation kit, according to the manufacturer's instructions. HSC cell cycle distribution was detected using propidium iodide (PI) staining. Briefly, HSC cells were trypsinized, collected and then fixed and permeabilized using $70 \%(\mathrm{v} / \mathrm{v})$ cold ethanol for $2 \mathrm{~h}$ at room temperature. Cells were subsequently incubated with $10 \mu \mathrm{g} / \mathrm{ml}$ $\mathrm{PI} / 0.1 \%$ Triton X-100/0.1\% RNase in PBS solution at $37^{\circ} \mathrm{C}$ for $30 \mathrm{~min}$ in the dark. Stained cells were analyzed on a BD FACS Calibur (BD Biosciences) using a fluorescence emission wavelength of $585 \mathrm{~nm}$ after an excitation wavelength of $488 \mathrm{~nm}$. For each analysis, 10,000 events were evaluated, and DNA content was determined using ModFit LT v3.0 software (Verity Software House, Inc.).
Effect of changes in 11 $\beta$-HSD1 expression on the release of collagen in HSCs. Cells from each group were collected and the concentration of collagen was measured using the ProCell collagen colorimetric assay kit, according to the manufacturer's protocol. Briefly, Sircol dye reagent was added to the cell culture supernatants $(1,000 \mathrm{x} \mathrm{g} ; 10 \mathrm{~min}$; room temperature), stirred for $20 \mathrm{~min}$ at room temperature and centrifuged at $15,000 \mathrm{x} \mathrm{g}$ for $10 \mathrm{~min}$ at room temperature. The absorbance of the bound dye was measured at a wavelength of $555 \mathrm{~nm}$ on a spectrophotometer.

Statistical analysis. Statistical analyses were conducted using SPSS statistical software (version 17.0; SPSS, Inc.). At least three independent experiments were performed for each analysis. Data are expressed as the mean \pm standard deviation. The normality of the data was analyzed using the Kolmogorov-Smirnov test. The homoscedasticity of data was analyzed using the Levene test. For normally distributed data with homogeneity, differences among groups were analyzed using one-way ANOVA followed by Fisher's LSD post hoc test. Data containing $>3$ groups were compared with the control group using one-way ANOVA followed by Dunnett's post hoc test. For comparisons within groups (TGF- $\beta 1^{-}$and TGF- $\beta 1^{+}$) and among groups analyzed using two-way ANOVA followed by the Bonferroni post hoc test. For non-normally distributed data, the Kruskal-Wallis test followed by the Bonferroni post hoc test was used. $\mathrm{P}<0.05$ was considered to indicate a statistically significant difference.

\section{Results}

Role of 11 $\beta$-HSDl inhibition in liver fibrosis. As shown in Fig. 1A and B, excessive formation of fibrotic tissues was observed in the livers of rats treated with porcine serum (M group), whereas slight periportal inflammatory infiltration was observed in fibrotic rats treated with the $11 \beta-H S D 1$ 

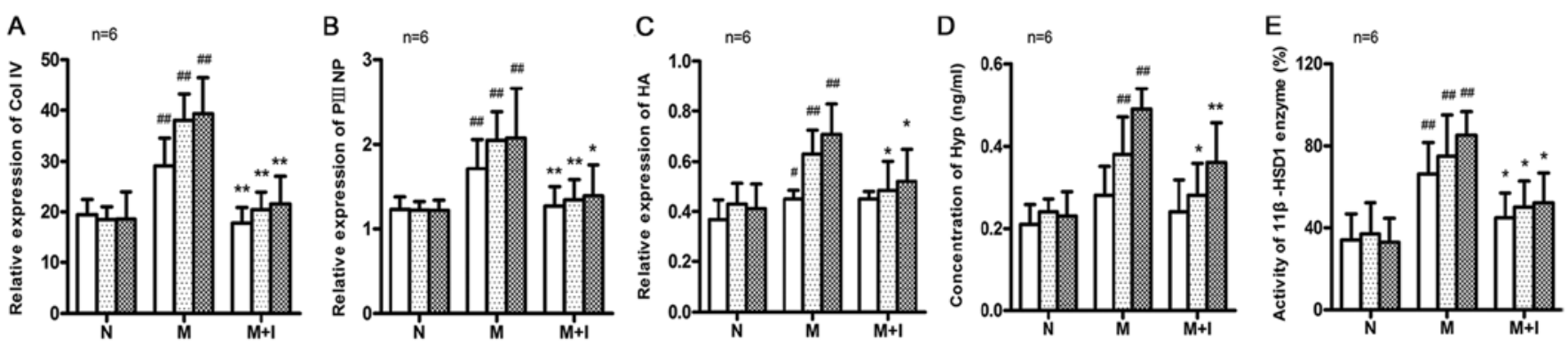

$\mathrm{F}$

G

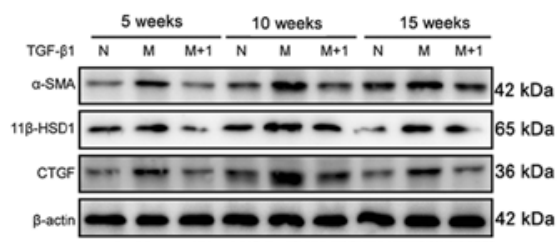

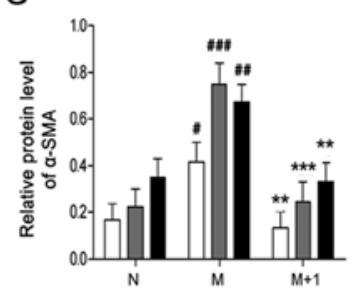

H

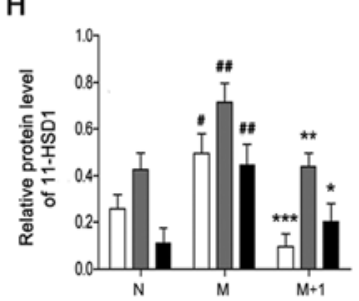

I

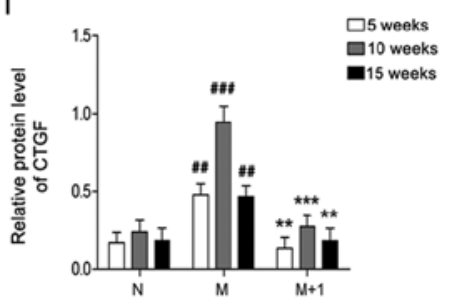

Figure 2. Effect of porcine serum on liver fibrosis. As liver fibrosis progressed, the expression of (A) Col IV, (B) PIIINP and (C) HA in the serum was measured. ${ }^{\#} \mathrm{P}<0.05,{ }^{\# \#} \mathrm{P}<0.01$ vs $\mathrm{N} ;{ }^{*} \mathrm{P}<0.05,{ }^{* *} \mathrm{P}<0.01$ vs. M. The liver (D) Hyp content and (E) $11 \beta$-HSD1 enzyme activity. ${ }^{\# \#} \mathrm{P}<0.01$ vs. $\mathrm{N} ;{ }^{* *} \mathrm{P}<0.01$ and ${ }^{*} \mathrm{P}<0.05$ vs. $\mathrm{M}$. Protein expression levels were (F) determined by western blotting and semi-quantified for $(\mathrm{G}) \alpha$-SMA, $(\mathrm{H}) 11 \beta$-HSD1 and $(\mathrm{I}) \mathrm{CTGF}$. ${ }^{*} \mathrm{P}<0.05,{ }^{\# \prime} \mathrm{P}<0.01$ and

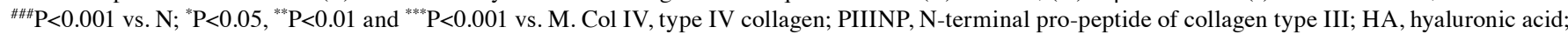
$\mathrm{N}$, normal control group; M, model group; M+I, 11ß-HSD1 inhibitor (BVT.2733) group; Hyp, hydroxyproline; 11 $\beta$-HSD1, 11 $\beta$-hydroxysteroid dehydrogenase 1; $\alpha$-SMA, $\alpha$-smooth muscle actin; CTGF, connective tissue growth factor.

inhibitor (M+I group). Histopathological analysis demonstrated that the degree of liver fibrosis was significantly higher in the $\mathrm{M}$ group compared with the $\mathrm{N}$ group $(\mathrm{P}<0.01)$ and the $\mathrm{M}+\mathrm{I}$ group $(\mathrm{P}<0.05)$. Together, the results suggested that $11 \beta$-HSD1 inhibition was effective against experimental liver fibrosis.

Serum markers of fibrosis are ameliorated after treatment with an 11 $\beta$-HSDl inhibitor. As hepatic fibrosis developed in the experimental model, the levels of Col IV, PIIINP and HA significantly increased in a time-dependent manner in the $\mathrm{M}$ group $(\mathrm{P}<0.01)$, which was not observed in the $\mathrm{N}$ group (Fig. 2A-C). Although the markers of liver fibrosis increased as hepatic fibrosis developed in the presence of the 11 $\beta$-HSD1 inhibitor ( $\mathrm{M}+\mathrm{I}$ group), the increase was significantly decreased compared with the $\mathrm{M}$ group $(\mathrm{P}<0.01)$.

11 $\beta$-HSDl inhibition decreases liver Hyp content and enzyme activity. Subsequently, whether the Hyp content and $11 \beta$-HSD1 activity in the liver tissues of fibrotic rats were altered in response to fibrosis induction was investigated. Hyp content and $11 \beta$-HSD1 enzyme activity were significantly increased in the $\mathrm{M}$ group compared with the $\mathrm{N}$ group $(\mathrm{P}<0.01$; Fig. 2D and E). By contrast, Hyp content and 11 $\beta$-HSD1 enzyme activity were significantly decreased in the $\mathrm{M}+\mathrm{I}$ group compared with the $\mathrm{M}$ group $(\mathrm{P}<0.01)$.

HSC activation decreases following $11 \beta$-HSD1 inhibition. Concomitant with serum markers of liver fibrosis, the levels of $\alpha$-SMA, $11 \beta$-HSD1 and CTGF gradually increased in the $\mathrm{M}$ group as hepatic fibrogenesis progressed compared with the $\mathrm{N}$ group $(\mathrm{P}<0.01$; Fig. $2 \mathrm{~F}-\mathrm{I})$. By contrast, protein expression levels of $\alpha$-SMA, $11 \beta$-HSD1 and CTGF in the liver tissues of the $\mathrm{M}+\mathrm{I}$ group were significantly decreased compared with the $\mathrm{M}$ group $(\mathrm{P}<0.01)$, indicating that the $11 \beta-\mathrm{HSD} 1$ inhibitor prevented HSC activation.

Alteration of $11 \beta-H S D 1$ during primary HSC activation. To determine whether 11 $\beta$-HSD1 expression could be altered during HSC activation, primary HSCs were freshly prepared and treated with TGF- $\beta 1$ in vitro. As shown in Fig. 3, the $11 \beta$-HSD1 and $\alpha$-SMA expression levels were higher after the TGF- $\beta 1$-mediated activation of primary HSCs compared with the controls.

Silencing of the 11 $\beta$-HSD1 gene in HSCs via siRNA transfection. As shown in Fig. 4A, the protein expression levels of 11 $\beta$-HSD1 in LX2-HSCs transfected with siRNA-11 $\beta$-HSD1 were significantly lower compared with the NC group $(\mathrm{P}<0.01)$. Furthermore, siRNA-mediated knockdown of $11 \beta$-HSD1 resulted in an $85 \%$ decreased in $11 \beta$-HSD1 expression levels. No significant difference in the expression levels of $11 \beta-H S D 1$ protein were observed between the $\mathrm{NC}$ and the $\mathrm{N}$ groups.

Overexpression of $11 \beta-H S D 1$ in HSCs following transfection of the pSuper-11 $\beta$-HSD1 expression vector. Eukaryotic expression of pSuper-11 $\beta$-HSD1 plasmids was identified and the sequencing results demonstrated that the recombinant plasmid had no deletions, mutations or other alterations (data not shown). As shown in Fig. 4B, 11 $\beta$-HSD1 protein expression in the pSuper group was significantly higher $(\sim \mathrm{x} 3.4)$ compared with the Vec group $(\mathrm{P}<0.01)$. No significant difference in $11 \beta$-HSD1 protein expression was observed between the Vec and $\mathrm{N}$ groups.

Effect of alterations in 11 $\beta$-HSDl expression on HSC proliferation. HSCs with 3 different expression levels of $11 \beta-H S D 1$ were challenged with TGF- $\beta 1(5 \mathrm{ng} / \mathrm{ml})$. Proliferation was 

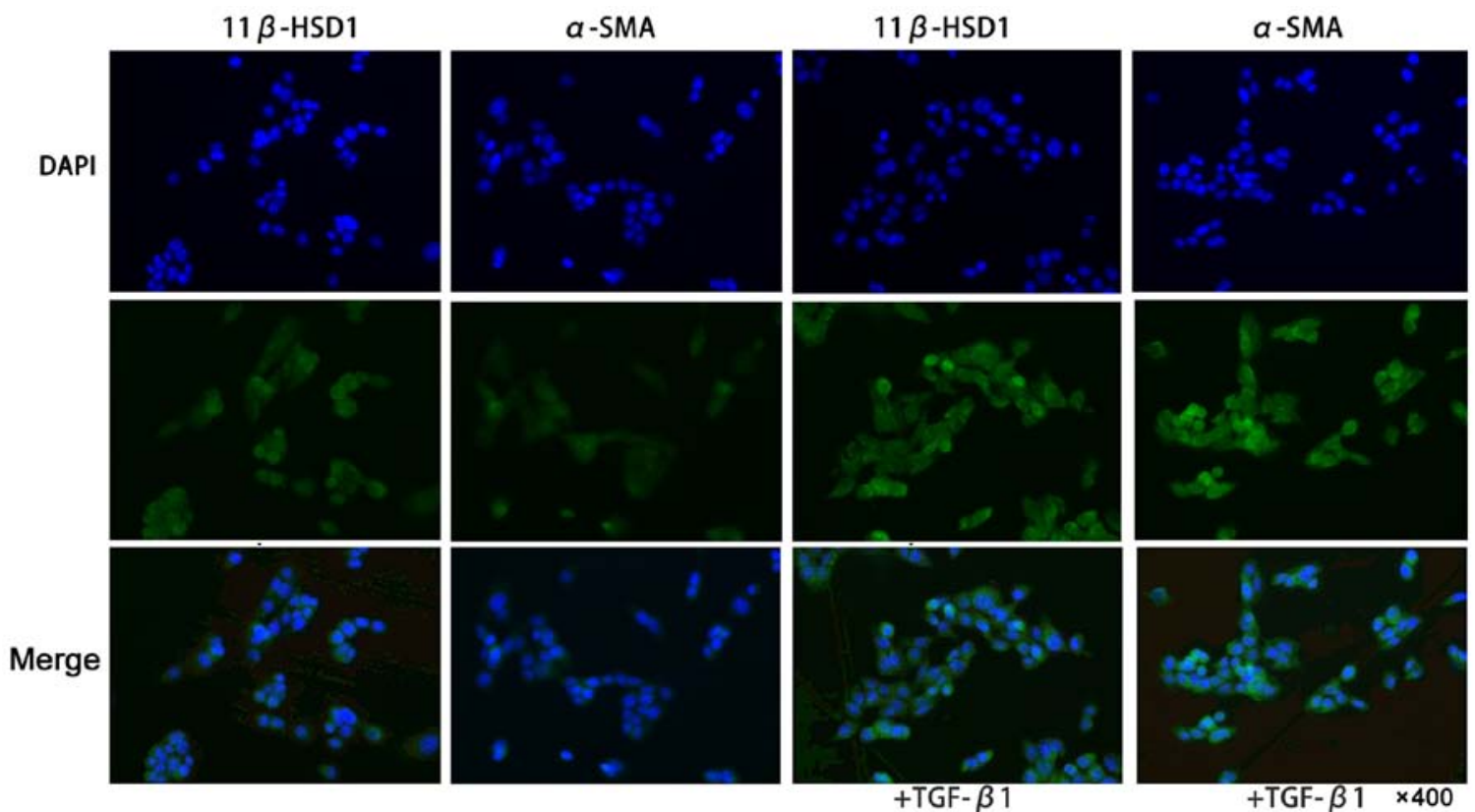

Figure 3. Upregulation of $11 \beta$-HSD1 during primary HSC activation. Primary HSCs were prepared and treated with or without TGF- $\beta 1$. Immunocytochemical staining of $\alpha$-SMA and 11 $\beta$-HSD1 protein expression was performed in HSCs with or without activation. Magnification, x400. 11 $\beta$-HSD1, 11 $\beta$-hydroxysteroid dehydrogenase 1 ; HSCs, hepatic stellate cells; TGF- $\beta 1$, transforming growth factor $\beta 1$; $\alpha$-SMA, $\alpha$-smooth muscle actin.
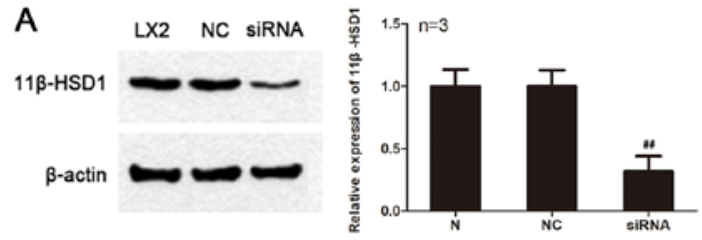

C

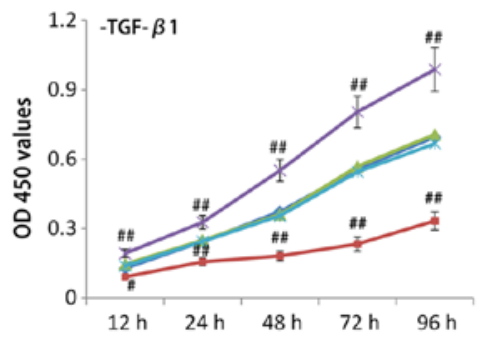

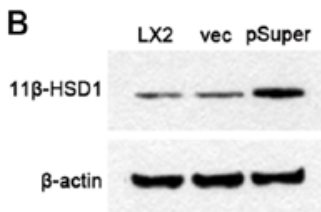

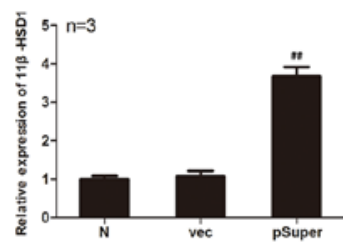

D

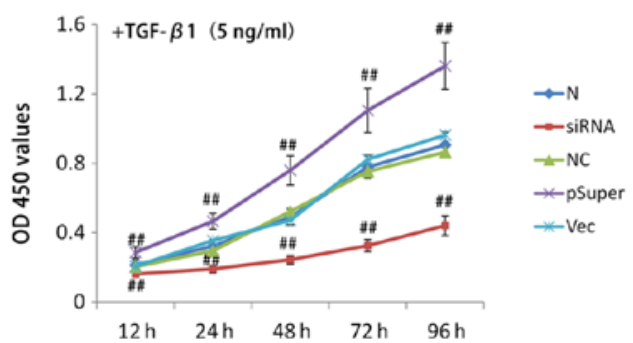

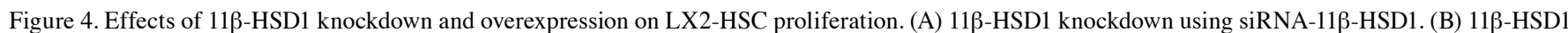
overexpression using pSuper-11 $\beta$-HSD1. ${ }^{\# \#} \mathrm{P}<0.01$ vs. N. (C) Effects of $11 \beta$-HSD1 knockdown and overexpression on LX2-HSC proliferation under normal culture conditions. (D) Effects of $11 \beta$-HSD1 knockdown and overexpression on LX2-HSC proliferation following TGF- $\beta 1$ induction. ${ }^{\# P} \mathrm{P}<0.05$ and ${ }^{\# \#} \mathrm{P}<0.01$ vs. N $11 \beta$-HSD1, 11 $\beta$-hydroxysteroid dehydrogenase 1; HSCs, hepatic stellate cells; siRNA, small interfering RNA; N, normal control group; NC, non-specific control; Vec, group in which LX2-HSCs were transfected with the pSuper-11 $\beta$-HSD1-vector plasmid; OD, optical density; TGF- $\beta 1$, transforming growth factor- $\beta 1$.

measured at different time points $(12,24,48,72$ and $96 \mathrm{~h})$ using the CCK-8 assay.

As observed in Fig. 4C, under normal culture conditions, LX2-HSC proliferation was higher in the pSuper group compared with the $\mathrm{N}$ group $(\mathrm{P}<0.01)$, whereas LX2-HSC proliferation was decreased in the siRNA group compared with the $\mathrm{N}$ group (12 h, $\mathrm{P}<0.05 ; 24,48,72$ and $96 \mathrm{~h}, \mathrm{P}<0.01)$. However, no significant differences were observed between the $\mathrm{NC}$ and Vec groups. Following TGF- $\beta 1$ induction, LX2-HSC proliferation was enhanced compared with untreated LX2-HSCs. Cell proliferation was significantly increased in the pSuper group compared with the $\mathrm{N}$ group $(\mathrm{P}<0.01)$.
Although LX2-HSC proliferation in the siRNA group was higher following TGF- $\beta 1$ treatment compared with untreated cells, the effect of TGF- $\beta 1$ on the LX2-HSC proliferation was significantly reduced compared with the $\mathrm{N}$ group $(\mathrm{P}<0.01)$. No significant differences were observed between the $\mathrm{NC}$ and $\mathrm{Vec}$ groups.

Effect of TGF- $\beta 1$ induction on cell cycle distribution in LX2-HSCs. HSC cycle distribution was detected via flow cytometry (Fig. 5). In the siRNA group (11 $\beta$-HSD1 knockdown group), the cells displayed increased $G_{0} / G_{1}$ phase arrest compared with the NC group. No significant differences were 
A
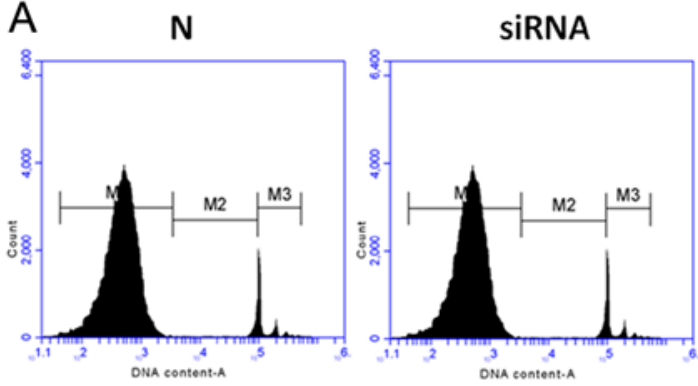

B

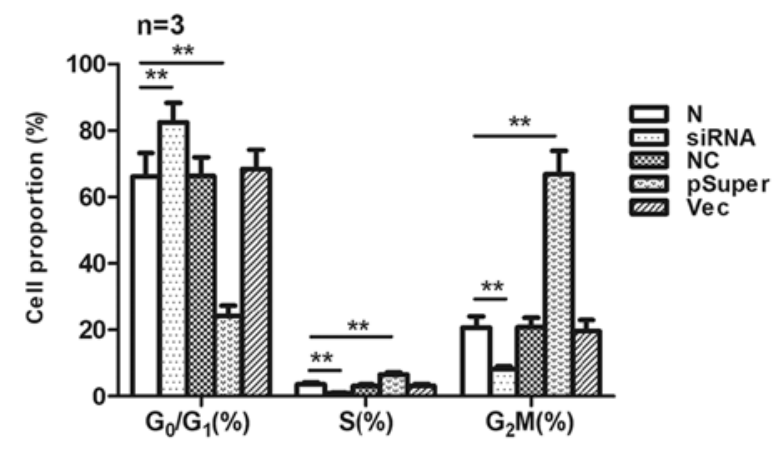

NC

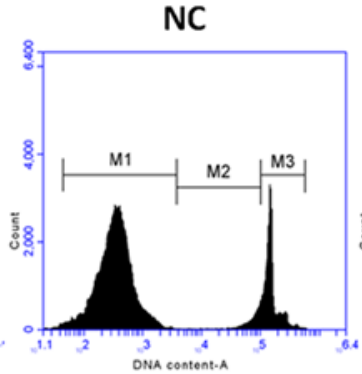

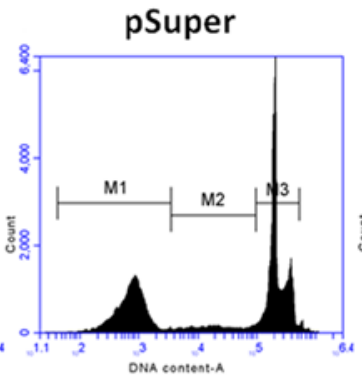

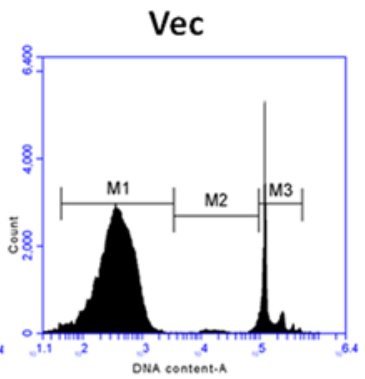

D
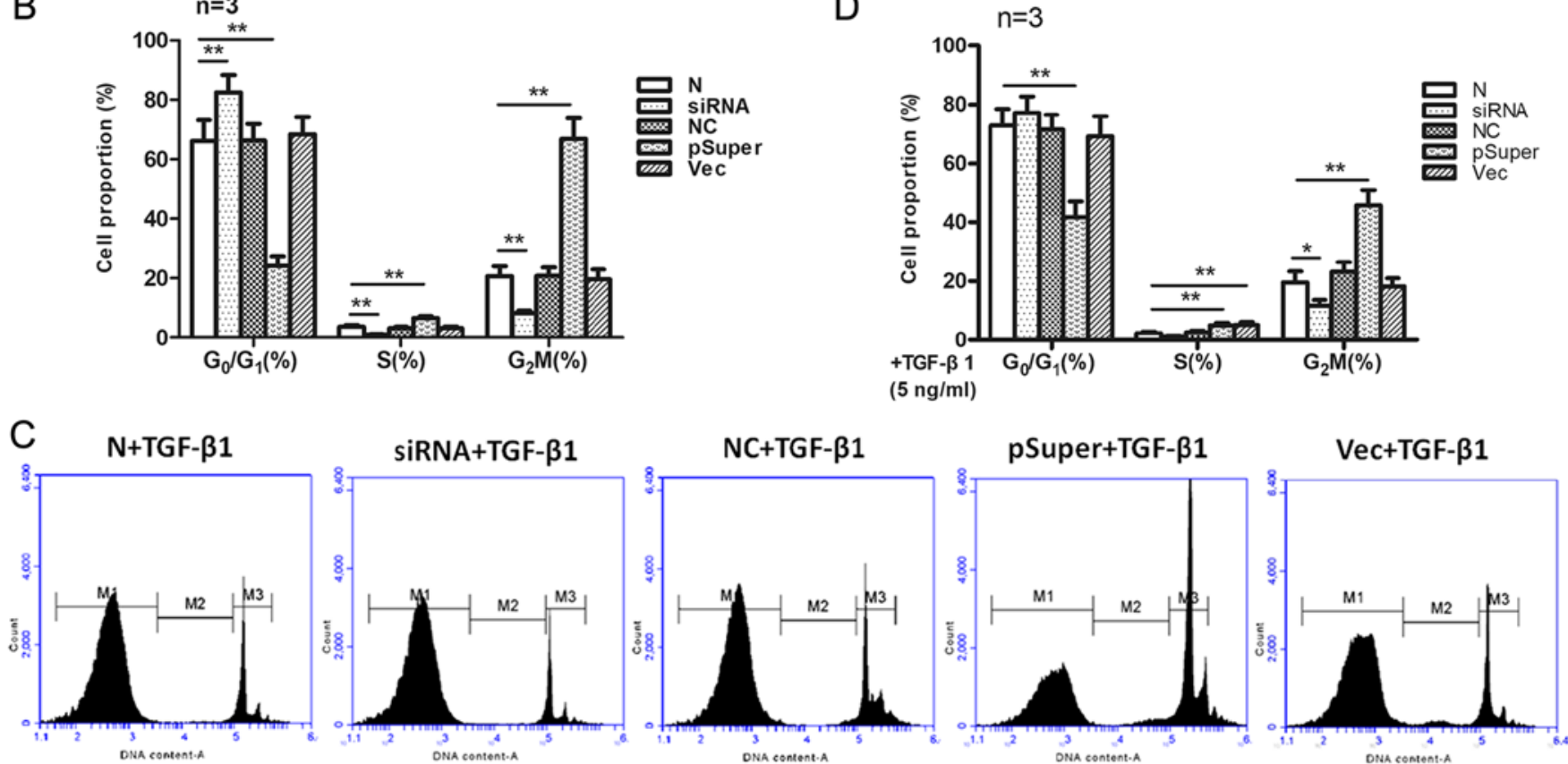

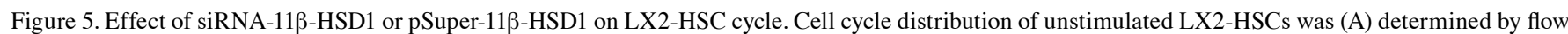
cytometry and (B) quantified. Cell cycle distribution of TGF- $\beta 1$-stimulated LX2-HSCs was (C) determined by flow cytometry and (D) quantified. "P<0.05, ${ }^{* *} \mathrm{P}<0.01$ vs. N. siRNA, small interfering RNA; $11 \beta$-HSD1, $11 \beta$-hydroxysteroid dehydrogenase 1 ; HSCs, hepatic stellate cells; TGF- $\beta 1$, transforming growth factor $\beta 1$; NC, non-specific control; N, normal control group; Vec, group in which LX2-HSCs were transfected with the pSuper-11/-HSD1-vector plasmid.

observed in the cell cycle distribution between the $\mathrm{NC}$ and $\mathrm{N}$ groups. In the pSuper group (11 $\beta$-HSD1 overexpression group), a decreased number of cells were in the $G_{0} / G_{1}$ phase and an increased number of cells were in the $S$ and $G_{2} / M$ phases compared with the $\mathrm{N}$ group. However, no significant differences were observed in cell cycle distribution between the Vec and $\mathrm{N}$ groups.

Influence of TGF- $\beta 1$ on the expression of $\alpha-S M A, 11 \beta-H S D 1$ and CTGF in vitro. TGF- $\beta 1$ treatment significantly increased the protein expression levels of $\alpha$-SMA, 11 $\beta$-HSD1 and CTGF in LX2-HSCs cells compared with untreated cells in all experimental groups (Fig. 6A-H). The pSuper group (11 $\beta$-HSD1 overexpression group) displayed altered the protein expression levels of $\alpha$-SMA, $11 \beta$-HSD1 and CTGF (Fig. 6E-H) to a greater extent compared with the siRNA group (11 $\beta$-HSD1 knockdown group; Fig. 6A-D), whereas no statistical differences were observed between the $\mathrm{NC}$ and Vec groups (Fig. 6A-H).

Effect of TGF- $\beta 1$ on collagen release and $11 \beta$-HSDI enzyme activity in HSCs in culture. As shown in Fig. 6I and J, LX2-HSCs in the pSuper group displayed increased collagen secretion, which was associated with enhanced 11 $\beta$-HSD1 enzyme activity, compared with the control group. By contrast, LX2-HSC collagen secretion was significantly reduced in the siRNA group, which was accompanied by a decrease in $11 \beta$-HSD1 enzyme activity compared with the control group. No significant differences were observed between the NC and Vec groups. Following TGF- $\beta 1$ induction, collagen secretion and $11 \beta$-HSD1 enzyme activity was increased in all experimental groups. Significant increases in these parameters were observed in the pSuper group.

\section{Discussion}

Consistent with previous studies $(27,32,33)$, the present study indicated that there was an increase in collagen fibers in the liver, which was associated with significantly elevated levels of Hyp, and serum Col IV, HA and PIIINP in an experimental rat model of hepatic fibrosis compared with control rats.

$11 \beta-H S D 1$ is a key enzyme that catalyzes GC synthesis and promotes the conversion of GCs to active forms (34). It is a bidirectional catalytic enzyme with redox capacity, which catalyzes the conversion between the biologically inactive 
A

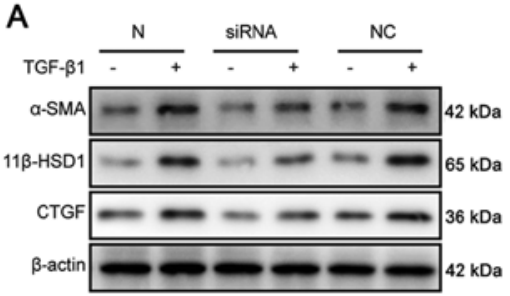

E

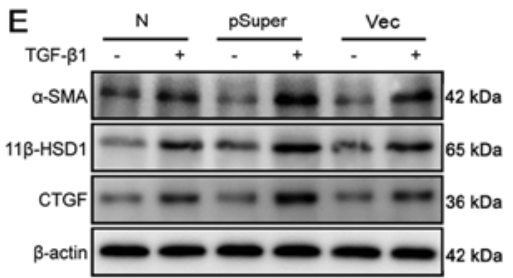

I

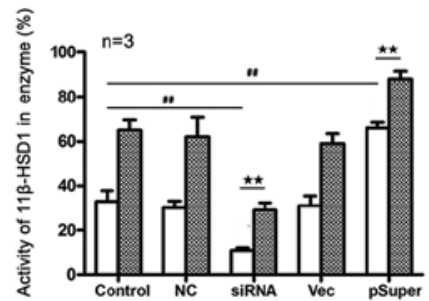

B

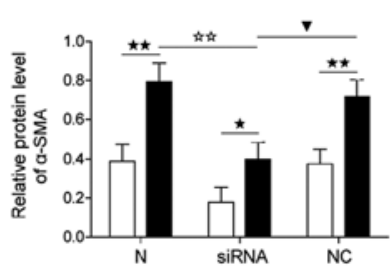

$\mathrm{F}$

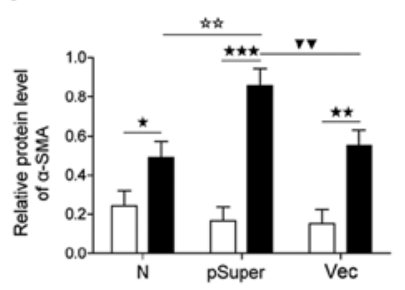

C

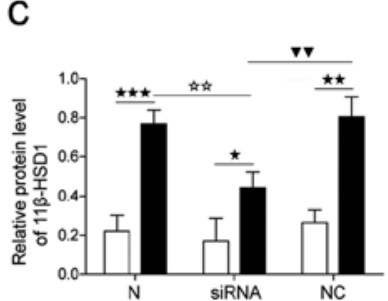

G

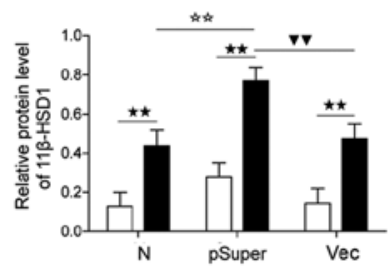

D

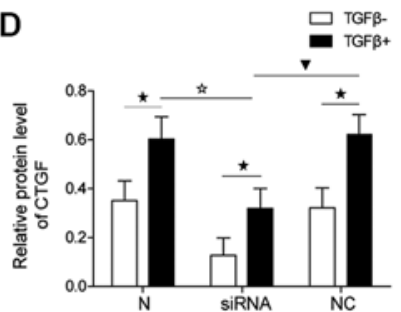

$\mathrm{H}$

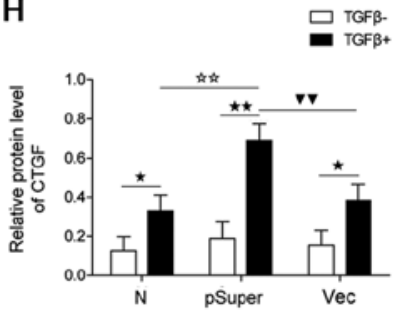

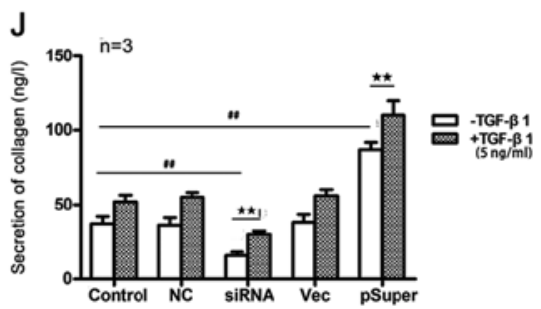

Figure 6. Effects of siRNA-11 $\beta$-HSD1 or pSuper-11 $\beta$-HSD1 on protein levels of $\alpha$-SMA, $11 \beta$-HSD1 and CTGF, enzyme activity of $11 \beta$-HSD1 and collagen secretion in LX2-HSCs. Protein expression levels were (A) determined by western blotting and semi-quantified for (B) $\alpha$-SMA, (C) $11 \beta$-HSD1 (D) CTGF following siRNA transfection. Protein expression levels were (E) determined by western blotting and semi-quantified for (F) $\alpha$-SMA, (G) $11 \beta-\mathrm{HSD} 1$ and

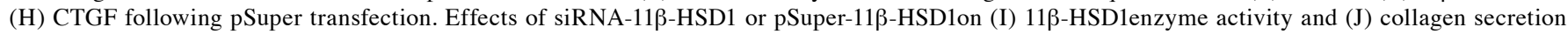

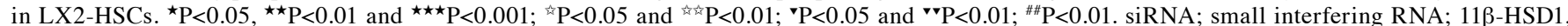
$11 \beta$-hydroxysteroid dehydrogenase 1; $\alpha$-SMA, $\alpha$-smooth muscle actin; CTGF, connective tissue growth factor; HSCs, hepatic stellate cells; N, normal control group; NC, non-specific control; Vec, group in which LX2-HSCs were transfected with the pSuper-11 $\beta$-HSD1-vector plasmid; TGF- $\beta 1$, transforming growth factor $\beta 1$.

forms of cortisol (cortisone) and the biologically active form (hydrocortisone) (35). 11 $\beta$-HSD1 is distributed in the liver, fat and kidney, as well as other organs, and serves various physiological roles, such as the intracellular metabolism of GCs and oxysterol metabolism, while its aberrant expression is associated with insulin resistance, visceral obesity and hypotension (36). In the present study, a hepatic fibrosis rat model was established by intraperitoneal injection of porcine serum. Alterations in $11 \beta$-HSD1 expression and biochemical parameters associated with the development of hepatic fibrosis were systematically evaluated. The results demonstrated that, in addition to the progression of liver fibrosis, 11 $\beta$-HSD1 expression levels increased in the liver, which may be attributed to enhanced $11 \beta-H S D 1$ activity and increased levels of markers of liver fibrosis, including Col IV, HA, PIIINP, $\alpha$-SMA and CTGF. The use of BVT.233, an inhibitor of 11 $\beta$-HSD1, markedly reduced levels of the biochemical markers of liver fibrosis and the severity of hepatic fibrosis. Subsequently, the results suggested that $11 \beta$-HSD1 overexpression promoted cell cycle progression, enhanced LX2-HSC proliferation, increased $\alpha$-SMA, CTGF and collagen secretion, and induced TGF- $\beta 1$ in LX2-HSCs. By contrast, 11 $\beta$-HSD1 knockdown displayed the opposite effects, including diminishing TGF- $\beta 1$-mediated stimulation of LX2-HSCs. The results suggested that $11 \beta$-HSD1 may participate in the development and progression of hepatic fibrosis by activating HSCs and regulating the expression of profibrotic markers.
Several studies on hepatic $11 \beta$-HSD1 have generated conflicting results. For example, Konopelska et al (37) reported that there was no association between hepatic 11 $\beta$-HSD1 expression and the pathology of fatty liver or non-alcoholic steatohepatitis (NASH) in humans, whereas Ahmed et al (38) suggested that in the early stages of nonalcoholic fatty liver disease (NAFLD), with steatosis alone, hepatic 11 $\beta$-HSD1 activity decreases with the progression to NASH, which is associated with increased 11 $\beta$-HSD1 levels. Notably, a more recent study conducted by Zou et al (39) demonstrated that specific deletion or inhibition of 11 $\beta$-HSD1 enhances the activation of HSCs in a murine model of liver fibrosis induced by carbon tetrachloride $\left(\mathrm{CCl}_{4}\right)$, which contradicts the results of the present study that used a rat model of liver fibrosis induced by persistent immune injury. In the face of this disagreement, independent experiments were carefully performed, and the findings were confirmed in the present study. There is a possibility that the measured outcomes varied due to the differences in animal models of liver fibrosis induced by chronic and acute liver injury. Chemical liver injury induced by $\mathrm{CCl}_{4}$ is the usual fibrosis model of acute liver injury; however, in the present study, porcine serum was used to induce liver fibrosis. Chronic viral hepatitis, especially chronic hepatitis B, is the major cause of liver fibrosis in China, and liver fibrosis caused by viral hepatitis is a process of chronic immune injury rather than a simple, acute chemical injury (40). Therefore, heterogeneous serum samples were selected to induce hepatic fibrosis 
in rats in the present study. Notably, Chen et al (41) reported that gossypol, an inhibitor of 11 $\beta$-HSD1, ameliorates liver fibrosis in a rat model of type 2 diabetes-related liver fibrosis, which was consistent with the observations of the present study, suggesting the antifibrotic effects of the $11 \beta$-HSD1 specific siRNA and inhibitor in rats. In addition, another study demonstrated that gossypol had an antifibrotic effect on lung fibrosis (42). Chen et al (41) demonstrated that the number of activated HSCs is significantly reduced following treatment with the $11 \beta$-HSD1 inhibitor. Indeed, the present study demonstrated that a decrease in 11 $\beta$-HSD1 expression significantly inhibited LX2 cell proliferation, with cell cycle arrested in the $G_{0} / G_{1}$ phase. In support of the role of $11 \beta$-HSD1 in cell cycle, $11 \beta$-HSD1 overexpression significantly promoted LX2 cell proliferation with increased numbers of cells in the $\mathrm{S}$ and $\mathrm{G}_{2} / \mathrm{M}$ phases. Given the key events in liver fibrosis, including HSC activation and proliferation, the present study hypothesized that there may be a mechanism that partially explains why the inhibition of $11 \beta$-HSD1 led to an antifibrotic effect. The results of the present study and the aforementioned studies have provided scientific evidence that inhibiting $11 \beta$-HSD1 holds therapeutic potential for chronic inflammatory liver fibrosis.

As 11 $\beta$-HSD1 blocks hydroxycortisone, the active form that can activate HSCs, it is worth determining whether the hydroxycortisone could rescue $11 \beta$-HSD1 inhibition. Collectively, the study of $11 \beta$-HSD1 in liver fibrosis requires further investigation to improve the understanding of the role of $11 \beta$-HSD1 and its underlying mechanisms in liver fibrosis.

In conclusion, the results suggested that upregulation of $11 \beta-H S D 1$ in the liver may be associated with the progression and development of liver fibrogenesis, and its mechanism may be related to HSC activation and proliferation, as well as increased CTGF and $\alpha$-SMA production.

\section{Acknowledgements}

Not applicable.

\section{Funding}

The present study was financially supported by the National Natural Science Foundation of China (grant no. 81771827).

\section{Availability of data and materials}

The datasets used and/or analyzed during the current study are available from the corresponding author on reasonable request.

\section{Authors' contributions}

WX and ZGL designed the study. WX, MHL, PFR, HYZ, JG and YQP performed the experiments. WX collected the data. WX, MHL, HYG and ZGL analyzed the data. WX, PFR, HYZ, JG and YQP interpreted the data. WX and ZGL drafted the manuscript, which was revised for content by MHL and HYG. All authors read and approved the final manuscript.

\section{Ethics approval and consent to participate}

The present study was approved by the Institutional Animal Care and Use Committee [Xiang license no. SCXK (Xiang) 2011-0003]. All procedures involving animals were in accordance with the ethical standards of the institution or practice at which the studies were conducted.

\section{Patient consent for publication}

Not applicable.

\section{Competing interests}

The authors declare that they have no competing interests.

\section{References}

1. Eijken M, Hewison M, Cooper MS, de Jong FH, Chiba H, Stewart PM, Uitterlinden AG, Pols HA and van Leeuwen JP: 11beta-Hydroxysteroid dehydrogenase expression and glucocorticoid synthesis are directed by a molecular switch during osteoblast differentiation. Mol Endocrinol 19: 621-631, 2005.

2. Gyllenhammer LE, Alderete TL, Mahurka S, Allayee H and Goran MI: Adipose tissue 11 $\beta$ HSD1 gene expression, $\beta c e l l$ function and ectopic fat in obese African Americans versus Hispanics. Obesity (Silver Spring) 22: 14-18, 2014

3. Tomlinson JW, Walker EA, Bujalska IJ, Draper N, Lavery GG, Cooper MS, Hewison M and Stewart PM: 11beta-hydroxysteroid dehydrogenase type 1: A tissue-specific regulator of glucocorticoid response. Endocr Rev 25: 831-866, 2004.

4. Wake DJ and Walker BR: 11 beta-hydroxysteroid dehydrogenase type 1 in obesity and the metabolic syndrome. Mol Cell Endocrinol 215: 45-54, 2004.

5. Chapman K, Holmes M and Seckl J: 11 $\beta$-hydroxysteroid dehydrogenases: Intracellular gate-keepers of tissue glucocorticoid action. Physiol Rev 93: 1139-1206, 2013.

6. Necela BM and Cidlowski JA: Mechanisms of glucocorticoid receptor action in noninflammatory and inflammatory cells. Proc Am Thorac Soc 1: 239-246, 2004.

7. Rhen T and Cidlowski JA: Antiinflammatory action of glucocorticoids - new mechanisms for old drugs. N Engl J Med 353: 1711-1723, 2005.

8. Zhang TY and Daynes RA: Macrophages from 11beta-hydroxysteroid dehydrogenase type 1-deficient mice exhibit an increased sensitivity to lipopolysaccharide stimulation due to TGF-beta-mediated up-regulation of SHIP1 expression. J Immunol 179: 6325-6335, 2007.

9. Gilmour JS, Coutinho AE, Cailhier JF, Man TY, Clay M Thomas G, Harris HJ, Mullins JJ, Seckl JR, Savill JS, et al: Local amplification of glucocorticoids by 11 beta-hydroxysteroid dehydrogenase type 1 promotes macrophage phagocytosis of apoptotic leukocytes. J Immunol 176: 7605-7611, 2006.

10. Ezhilarasan D, Sokal E and Najimi M: Hepatic fibrosis: It is time to go with hepatic stellate cell-specific therapeutic targets. Hepatobiliary Pancreat Dis Int 17: 192-197, 2018.

11. Koyama Y, Xu J, Liu X and Brenner DA: New Developments on the Treatment of Liver Fibrosis. Dig Dis 34: 589-596, 2016.

12. Schnabl B, Kweon YO, Frederick JP, Wang XF, Rippe RA and Brenner DA: The role of Smad3 in mediating mouse hepatic stellate cell activation. Hepatology 34: 89-100, 2001.

13. Pellicoro A, Ramachandran P, Iredale JP and Fallowfield JA: Liver fibrosis and repair: Immune regulation of wound healing in a solid organ. Nat Rev Immunol 14: 181-194, 2014.

14. Fabris L, Strazzabosco M, Crosby HA, Ballardini G, Hubscher SG, Kelly DA, Neuberger JM, Strain AJ and Joplin R: Characterization and isolation of ductular cells coexpressing neural cell adhesion molecule and Bcl-2 from primary cholangiopathies and ductal plate malformations. Am J Pathol 156: 1599-1612, 2000

15. Huang YH, Chen YX, Zhang LJ, Chen ZX and Wang XZ: Hydrodynamics-based transfection of rat interleukin-10 gene attenuates porcine serum-induced liver fibrosis in rats by inhibiting the activation of hepatic stellate cells. Int $\mathrm{J}$ Mol Med 34: 677-686, 2014. 
16. Pereira RM, dos Santos RA, da Costa Dias FL, Teixeira MM and Simões e Silva AC: Renin-angiotensin system in the pathogenesis of liver fibrosis. World J Gastroenterol 15: 2579-2586, 2009.

17. Lam BP, Jeffers T, Younoszai Z, Fazel Y and Younossi ZM: The changing landscape of hepatitis $C$ virus therapy: Focus on interferon-free treatment. Therap Adv Gastroenterol 8: 298-312, 2015.

18. Friedman SL: Liver fibrosis - from bench to bedside. J Hepatol 38 (Suppl 1): S38-S53, 2003.

19. Inagaki Y and Okazaki I: Emerging insights into Transforming growth factor beta Smad signal in hepatic fibrogenesis. Gut 56: 284-292, 2007.

20. Kluwe J, Mencin A and Schwabe RF: Toll-like receptors, wound healing, and carcinogenesis. J Mol Med (Berl) 87: 125-138, 2009.

21. Görbig MN, Ginès P, Bataller R, Nicolás JM, Garcia-Ramallo E, Tobías E, Titos E, Rey MJ, Clària J, Arroyo V, et al: Atrial natriuretic peptide antagonizes endothelin-induced calcium increase and cell contraction in cultured human hepatic stellate cells. Hepatology 30: 501-509, 1999.

22. Grieb G, Steffens G, Pallua N, Bernhagen J and Bucala R: Circulating fibrocytes - biology and mechanisms in wound healing and scar formation. Int Rev Cell Mol Biol 291: 1-19, 2011

23. Schlernitzauer A, Oiry C, Hamad R, Galas S, Cortade F, Chabi B, Casas F, Pessemesse L, Fouret G, Feillet-Coudray C, et al: Chicoric acid is an antioxidant molecule that stimulates AMP kinase pathway in L6 myotubes and extends lifespan in Caenorhabditis elegans. PLoS One 8: e78788, 2013.

24. Di Sario A, Bendia E, Svegliati Baroni G, Ridolfi F, Casini A, Ceni E, Saccomanno S, Marzioni M, Trozzi L, Sterpetti P, et al: Effect of pirfenidone on rat hepatic stellate cell proliferation and collagen production. J Hepatol 37: 584-591, 2002.

25. Iredale JP: A cut above the rest? MMP-8 and liver fibrosis gene therapy. Gastroenterology 126: 1199-1201, 2004.

26. Cremer MA, Rosloniec EF and Kang AH: The cartilage collagens: A review of their structure, organization, and role in the pathogenesis of experimental arthritis in animals and in human rheumatic disease. J Mol Med (Berl) 76: 275-288, 1998.

27. Bhunchet E, Eishi Y and Wake K: Contribution of immune response to the hepatic fibrosis induced by porcine serum. Hepatology 23: 811-817, 1996.

28. Kim JH, Lee S, Lee MY and Shin HK: Therapeutic effect of Soshiho-tang, a traditional herbal formula, on liver fibrosis or cirrhosis in animal models: A systematic review and meta-analysis. J Ethnopharmacol 154: 1-16, 2014.

29. Andrade RG, Gotardo BM, Assis BC, Mengel J and Andrade ZA: Immunological tolerance to pig-serum partially inhibits the formation of septal fibrosis of the liver in Capillaria hepatica-infected rats. Mem Inst Oswaldo Cruz 99: 703-707, 2004

30. Cai DY, Zhao G, Chen JC, Ye GM, Bing FH and Fan BW: Therapeutic effect of Zijin capsule in liver fibrosis in rats. World J Gastroenterol 4: 260-263, 1998.
31. Goodman ZD: Grading and staging systems for inflammation and fibrosis in chronic liver diseases. J Hepatol 47: 598-607, 2007.

32. Lee JH, Jang EJ, Seo HL, Ku SK, Lee JR, Shin SS, Park SD, Kim SC and Kim YW: Sauchinone attenuates liver fibrosis and hepatic stellate cell activation through TGF- $\beta /$ Smad signaling pathway. Chem Biol Interact 224: 58-67, 2014.

33. Yang Y, Wang H, Lv X, Wang Q, Zhao H, Yang F, Yang Y and Li J: Involvement of cAMP-PKA pathway in adenosine A1 and A2A receptor-mediated regulation of acetaldehyde-induced activation of HSCs. Biochimie 115: 59-70, 2015.

34. Legeza B, Marcolongo P, Gamberucci A, Varga V, Bánhegyi G, Benedetti A and Odermatt A: Fructose, Glucocorticoids and Adipose Tissue: Implications for the Metabolic Syndrome. Nutrients 9: 426, 2017.

35. Morton NM, Holmes MC, Fiévet C, Staels B, Tailleux A, Mullins JJ and Seckl JR: Improved lipid and lipoprotein profile, hepatic insulin sensitivity, and glucose tolerance in 11beta-hydroxysteroid dehydrogenase type 1 null mice. J Biol Chem 276: 41293-41300, 2001.

36. Seckl JR, Morton NM, Chapman KE and Walker BR: Glucocorticoids and 11beta-hydroxysteroid dehydrogenase in adipose tissue. Recent Prog Horm Res 59: 359-393, 2004.

37. Konopelska S, Kienitz T, Hughes B, Pirlich M, Bauditz J, Lochs H, Strasburger CJ, Stewart PM and Quinkler M: Hepatic 11beta-HSD1 mRNA expression in fatty liver and nonalcoholic steatohepatitis. Clin Endocrinol (Oxf) 70: 554-560, 2009.

38. Ahmed A, Rabbitt E, Brady T, Brown C, Guest P, Bujalska IJ, Doig C, Newsome PN, Hubscher S, Elias E, et al: A switch in hepatic cortisol metabolism across the spectrum of non alcoholic fatty liver disease. PLoS One 7: e29531, 2012.

39. Zou X, Ramachandran P, Kendall TJ, Pellicoro A, Dora E, Aucott RL, Manwani K, Man TY, Chapman KE, Henderson NC, et al: 11Beta-hydroxysteroid dehydrogenase-1 deficiency or inhibition enhances hepatic myofibroblast activation in murine liver fibrosis. Hepatology 67: 2167-2181, 2018.

40. Yang $\mathrm{R}, \mathrm{Xu} \mathrm{Y}$, Dai Z, Lin X and Wang H: The Immunologic Role of Gut Microbiota in Patients with Chronic HBV Infection. J Immunol Res 2018: 2361963, 2018.

41. Chen G, Wang R, Chen H, Wu L, Ge RS and Wang Y: Gossypol ameliorates liver fibrosis in diabetic rats induced by high-fat diet and streptozocin. Life Sci 149: 58-64, 2016.

42. Kottmann RM, Trawick E, Judge JL, Wahl LA, Epa AP, Owens KM, Thatcher TH, Phipps RP and Sime PJ: Pharmacologic inhibition of lactate production prevents myofibroblast differentiation. Am J Physiol Lung Cell Mol Physiol 309: L1305-L1312, 2015.

This work is licensed under a Creative Commons Attribution-NonCommercial-NoDerivatives 4.0 International (CC BY-NC-ND 4.0) License. 